\title{
The Clash: The Danish Supreme Court Defies the CJEU in the Ajos Case
}

\section{Catherine Jacqueson}

\section{(2) OpenEdition}

1 Journals

\section{Electronic version}

URL: https://journals.openedition.org/rdctss/2527

DOI: $10.4000 /$ rdctss. 2527

ISSN: 2262-9815

\section{Publisher}

Centre de droit comparé du travail et de la sécurité sociale

\section{Printed version}

Date of publication: 1 December 2017

Number of pages: $250-253$

ISSN: $2117-4350$

\section{Electronic reference}

Catherine Jacqueson, "The Clash: The Danish Supreme Court Defies the CJEU in the Ajos Case", Revue de droit comparé du travail et de la sécurité sociale [Online], 4 | 2017, Online since 01 November 2021, connection on 04 December 2021. URL: http://journals.openedition.org/rdctss/2527 ; DOI: https:// doi.org/10.4000/rdctss. 2527

\section{(c) (†) $९$}

Revue de droit comparé du travail et de la sécurité sociale est mise à disposition selon les termes de la Licence Creative Commons Attribution - Pas d'Utilisation Commerciale - Pas de Modification 4.0 International. 


\section{CATHERINE JACQUESON}

COPENHAgEN UNIVERSITY

\section{The Clash : \\ The Danish Supreme Court Defies the CJEU in the Ajos Case}

On the 6th of December 2016, for the first time, the Danish Supreme Court (Højesteret) openly refused to apply a preliminary ruling of the Court of Justice of the European Union (hereafter CJEU). ${ }^{1}$ The case concerned a discrimination on grounds of age in an employment relationship. The Danish Court had urged the CJEU to reconsider its case-law compelling private employers to respect this principle. ${ }^{2}$ According to the Danish Supreme Court, it conflicts with the principle of legal certainty. While the CJEU confirmed its previous case-law, the Danish Supreme Court refused to follow it. It ruled that the legislator has not transferred sovereignty to the EU in this respect. Consequently, general principles of EU law and the EU Charter on Fundamental Rights cannot impose obligations on private parties in Denmark.

\section{I - THE MANGOLD CASE-LAW}

The CJEU had already ruled in C-499/08 of 2010, Ole Andersen that Denmark had infringed the employment directive establishing a framework for equal treatment. ${ }^{3}$ According to the Danish Act on Salaried Employees, dismissed employees were not entitled to a severance allowance if they were entitled to a pension financed by their employer. The CJEU ruled that this constituted a discrimination on grounds of age contrary to the directive. Entitlement to the oldage pension was indeed subject to a minimum age requirement of 60 years. The Danish law was finally amended in 2015 putting it in line with the Court's ruling. The Ajos case concerns the period prior to the legislative change: can an employer from the private sector be subject to the principle of non-discrimination on grounds of age? It is well-known that a directive cannot impose obligations upon private. Yet, in Mangold (C-144/04), the Court had found that non-discrimination on grounds of age is a general principle of EU law which could be applied in cases between two private persons. Therefore, the Maritime and Commercial Court ruled in first instance in favour of the employee. The Confederation of Danish Industry (Dansk Industri) acting on behalf of the undertaking Ajos, appealed the ruling. The Danish Supreme Court found it problematic that

1 Case 15/2014 Case no. 15/2014 Dansk Industri (DI) acting for Ajos A/S vs. The estate left by A. An unofficial translation of the ruling into English is available on the Danish Court's website:

http://www.supremecourt.dk/supremecourt/nyheder/pressemeddelelser/Documents/ Judgment\%2015-2014.pdf

2 Case 441/14 Dansk Industri v Rasmussen [2016].

3 Council Directive 2000/78 establishing a general framework for equal treatment in employment and occupation (OJ 2000 L 303, p. 16). 
an unwritten general principle of EU law could impose obligations on private employers. ${ }^{4}$ According to the Supreme Court, it was not possible to interpret Danish law in conformity with this principle. This would amount to a contra legem interpretation not required by EU law. Furthermore, in the Danish Court's opinion, the Mangold principle clashed with the principle of legal certainty where private parties should not be subject to obligations not clearly enunciated in the law. The Danish Court thus asked the CJEU (1) whether the Danish Act is contrary to the general principle of non-discrimination on grounds of age (2) whether this principle should be weighed against the principles of legal certainty and legitimate expectations.

\section{II - A CLEAR ANSWER AS CLEARLY REJECTED}

The CJEU's answer to the Danish court's questions and concerns is crystal clear: the Danish Court has to set aside the law which conflicts with the general principle of law if it cannot interpret it in conformity with this principle. The principle of legal certainty cherished by the Danish Court had no bearing on the CJEU. The answer of the Danish court was as clear as that of the CJEU: the general principle of non-discrimination on grounds of age cannot be applied to private employers in Denmark on the simple ground that Denmark has not transferred sovereignty to the EU in this respect. It is the first time that the Supreme Court refuses to apply a ruling of the CJEU. Yet, in its landmark decision on the constitutionality of the Maastricht Treaty of 1998, it had already ruled that it has the final say on the application of EU law in the kingdom. ${ }^{5}$

\section{III - LIMITED SOVEREIGNTY TRANSFER - THE MAASTRICHT DECISION}

Like other national supreme courts, the Danish Court had thus made clear that the application of EU law in Denmark is not unconditional. According to the Constitution, sovereignty has only been transferred to the EU where further specified. Therefore, in its Maastricht decision, the Supreme Court ruled that EU law is only applicable in the country if it respects the limits of the sovereignty transferred to the EU pursuant to the Acts of Accession. This would normally assumed to be the case and EU law and the CJEU's case law are thus in principle directly applicable in Denmark. Yet, the Supreme Court added that this is only a presumption and that in extraordinary situations, the Supreme Court would check whether this is really the case. If the Court with the required certainty can ascertain that the

4 For a detailed analysis of the issue, see Kristiansen, The growing conflict between European uniformity and national flexibility - The case of Danish flexicurity and European harmonization of working conditions, DJØF Publishing 2015, p. $230 \mathrm{ff}$.

5 Case 361/1997 of 6 April 1998. 
contested EU law provision falls outside the mandate given by Denmark to the EU, it would then not be applicable in the country. The Ajos case is a bit particular in this respect, as the Supreme Court checked whether sovereignty had been granted to the EU in the first place. It thus checked the constitutionality of the general principle of equal treatment on grounds of age and found that the Danish people had not transferred powers to the EU in this respect. The Supreme Court based its finding on the wording of the Accession Acts and essentially on their travaux préparatoires.

\section{IV - EVIDENCE OF LACK OF TRANSFER OF SOVEREIGNTY}

Looking at the Acts of Accession, the Danish Court emphasized that powers had been transferred to the EU within the limits specified in the Treaties and that Treaty provisions are directly applicable and form part of Danish law. By contrast, still according to the Danish Court, the legislator had not foreseen that the general principles of EU law and the Charter could impose obligations on private parties. This is the decisive factor for the Danish Supreme Court. As general principles are a creation of the CJEU, they do not initially have their source in Treaty provisions, and only provisions mentioned in the Treaties are transferred to the EU. While the Maastricht Treaty referred to the general principles (now Art. 6(3) TEU), according to the preparatory work to the Accession Act, they were not among the EU acts capable of being directly applicable in Denmark. By contrast, the only dissenting judge out of 9 judges emphasized that the Mangold principle was wellknown to the Danish legislator while accessing the Lisbon Treaty, and that nothing in the Act indicated that this principle should not apply in Denmark. Yet, for the majority of the judges, this argument was irrelevant. If there were no explicit mention to this principle in the Lisbon Accession Act, then it could not be assumed that the will of the legislator in the Maastricht Accession Act had been amended. Furthermore, the Supreme Court also referred to the Charter, which has a specific provision prohibiting discrimination on grounds of age (Art. 21). Yet, the Supreme Court relying on the travaux préparatoires to the Lisbon Accession Act and more specifically on the answer of the Ministry of Foreign Affairs to the Parliament concluded that the Charter could not impose obligation on citizens. Thus, Art. 21 and the remaining provisions of the Charter are not directly applicable to private in Denmark.

\section{V - SEPARATION OF POWERS AS THE UNDERLYING RATIONALE}

Following its finding that Denmark had not authorised the EU to impose obligations by way of general principle of EU law or by Charter provisions, the Danish Court added that in such a situation it had to respect the will of the legislator. Otherwise, it would act in breach of the constitutional principle of separation of powers between the legislator and the judiciary. ${ }^{6}$ This statement might implicitly refer to the difference between the role that courts play in Denmark and the CJEU in the EU. It could be seen as a criticism in disguise of

6 Kristiansen, "Grænser for EU-rettens umiddelbare anvendelighed i dansk ret - Om Højesterets dom i Ajos-sagen", Juristen 2017, p. 82. 
the CJEU as being too activist and dynamic in its interpretation and application of EU law. While the CJEU can assess the legality of EU acts in the light of general principles of EU law that it has itself 'created', such competence is alien to the Danish constitutional system. Thus, Danish Courts are not empowered to set aside a law based on an unwritten principle of law. In any event there is no such principle of equality in Danish constitutional law. ${ }^{7}$

\section{VI - SCOPE AND IMPACT}

The extraordinary situation has now arisen where EU law cannot be applied in Denmark. In assessing the will of Parliament, the preparatory work to the Accession Acts took a central place. In contrast, the ruling does not contest the horizontal direct effect of Treaty provisions as sovereignty has explicitly been transferred in this respect. Following the Danish ruling in Ajos, employees in the private sector are not entitled to a severance allowance if they are entitled to a pension financed by their employer. But, they might seek compensation for their loss before national courts.

The defiance of the Supreme Court could be seen from two opposite perspectives. From a perspective of Danish legal thinking, the ruling reinforces the principle of separation of powers, and upholds the principle of legal certainty shielding private parties and citizens from obligations not clearly enunciated in the law. In such a way, it could just be seen as a firm reminder to the CJEU of the division of tasks between national courts and the CJEU, each one being master in its own realm. The Danish court takes care of the interpretation of national law pursuant to its own constitutional set up whereas the CJEU follows its activist style of interpretation. Yet, the Supreme Court reveals its strong tights to traditional legal thinking based on the will of Parliament as expressed in the travaux préparatoires. Such rigid approach to sovereignty transfer further complicates the application of EU law in Denmark. Finally, from the perspective of EU law, the ruling can be read as sending more worrying signals of clash between levels of jurisdiction in a context where the EU is contested and the sovereign nation-state is praised anew. ${ }^{8}$ In such a light the ruling further exacerbates national differences and the conditionality of EU law.

7 Ibid. at $\mathrm{p} 83$.

8 See for example, Rask, Palmer Olsen and Sadl, "Competing Supremacies and Clashing Institutional Rationalities: The Danish Supreme Court's Decision in the Ajos Case and the National Limits of Judicial Cooperation", European Law Journal (2017) forthcoming. 